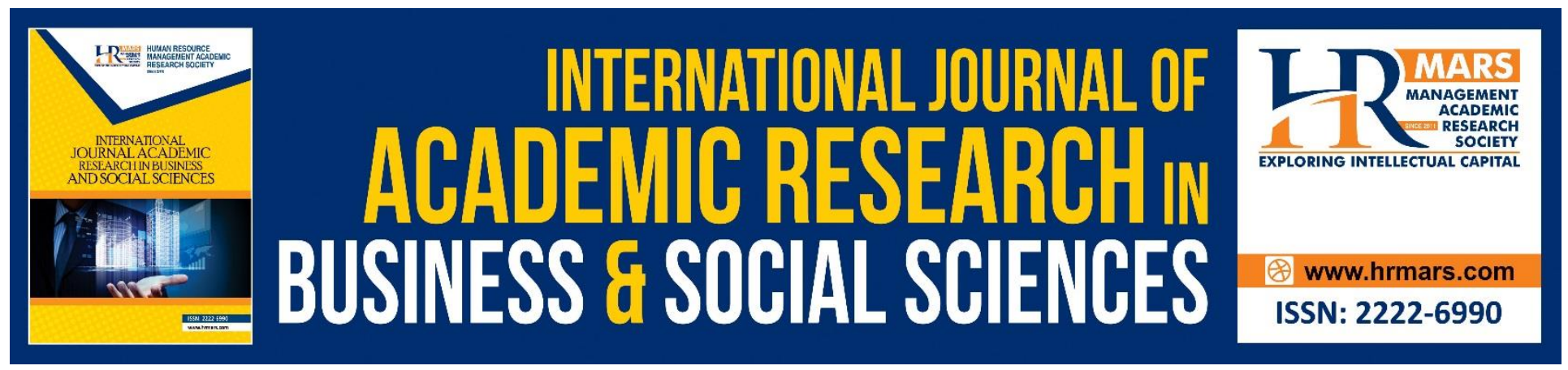

\title{
The Qur'an as an Approach to Construct the Curriculum of Values for the Secondary School Students to Prevent the Negative Impact of Social Media
}

\section{Nashaat Baioumy \& Yousef Al-Qudah}

To Link this Article: http://dx.doi.org/10.6007/IJARBSS/v8-i11/4910

DOI: $10.6007 /$ IJARBSS/v8-i11/4910

Received: 29 Oct 2018, Revised: 16 Nov 2018, Accepted: 26 Nov 2018

Published Online: 28 Nov 2018

In-Text Citation: (Baioumy \& Al-Qudah, 2018)

To Cite this Article: Baioumy, N., \& Al-Qudah, Y. (2018). The Qur'an as an Approach to Construct the Curriculum of Values for the Secondary School Students to Prevent the Negative Impact of Social Media. International Journal of Academic Research in Business and Social Sciences, 8(11), 374-381.

\section{Copyright: (c) 2018 The Author(s)}

Published by Human Resource Management Academic Research Society (www.hrmars.com)

This article is published under the Creative Commons Attribution (CC BY 4.0) license. Anyone may reproduce, distribute, translate and create derivative works of this article (for both commercial and non-commercial purposes), subject to full attribution to the original publication and authors. The full terms of this license may be seen at: http://creativecommons.org/licences/by/4.0/legalcode

Vol. 8, No. 11, 2018, Pg. 374 - 381

Full Terms \& Conditions of access and use can be found at http://hrmars.com/index.php/pages/detail/publication-ethics 


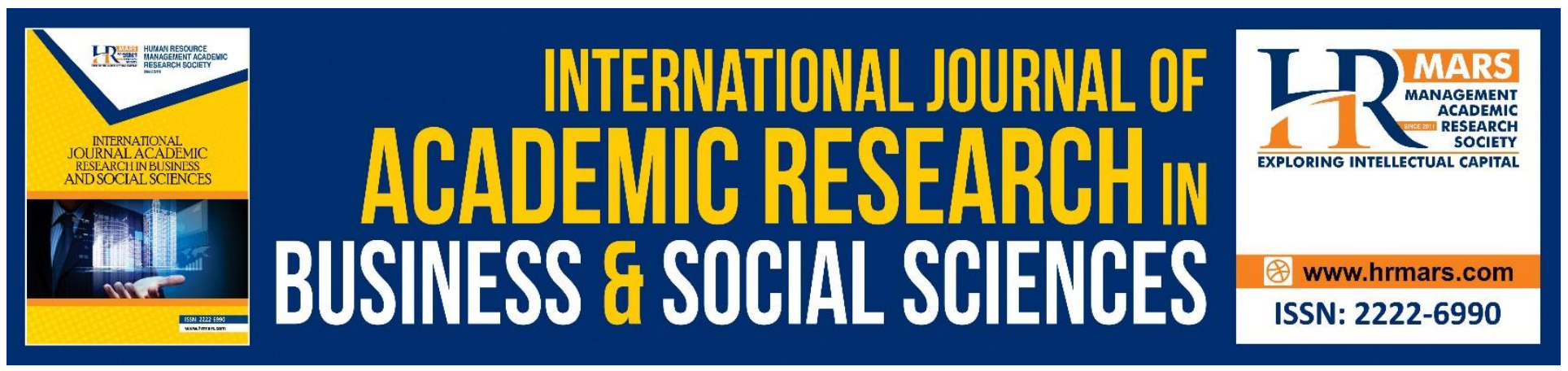

\title{
The Qur'an as an Approach to Construct the Curriculum of Values for the Secondary School Students to Prevent the Negative Impact of Social Media
}

\author{
Nashaat Baioumy \& Yousef Al-Qudah \\ Faculty of Islamic Contemporary Studies University of Sultan Zainal Abidin, 21300, Terengganu, \\ Malaysia
}

\begin{abstract}
Despite of the benefits that social media offered - which benefits the adolescents of secondary students in different aspects of study and life, but the whispered use in negative manners randomly, led to negative psychological, moral and educational impact on this group of students, that led to create an environment for mental illnesses, autism, the reasons to be concerned, confusion, depression, and the spread of bad morals such as spying, rumors, sexual harassment, animosities suicide, and the failure of many students at this stage in academic achievement. The current research is based on the inductive method and the analytical descriptive method to suggest the construction Curriculum of values for the secondary school students based on The Qur'an. The research resulted in a proposed conception of the values-based method of the Holy Quran to face the negative effects: psychological, moral, and study, as well as building positive values that protect adolescents and encourage them towards success and excellence psychological, moral and positive in the construction of community, the research recommends to construct the methods of values in the light of the Qur'an and Sunnah, to face the dangers of social media for university students, and students before the university.
\end{abstract}

Keywords: Quran, values, Approach, social media.

\section{THEORETICAL BACKGROUND OF THE SEARCH PROBLEM}

The majority of users of these media registered at least twice daily access, 9 times monthly, 14\% signed with no activity, $16 \%$ write each time they entered. The average number of friends foe each individual was 195 in South America 360, in Portugal 236, and in North America 200. (Jalal, 2012). 
INTERNATIONAL JOURNAL OF ACADEMIC RESEARCH IN BUSINESS AND SOCIAL SCIENCES Vol. 8, No. 11, Nov, 2018, E-ISSN: 2222-6990 C 2018 HRMARS

In the Arab world, the number of users of social media in 2013 was 74 million, of which $65 \%$ were males and 35\% were females. The majority of Internet users in the Middle East put social media of all kinds in the list of priorities for use. in the Middle East reached to 88\% (Al-Qudah, 2018).

Social media can cause serious damage to adolescents. In general, sitting for long hours can cause for the individual and for the adolescents in particular isolation and away from reality and the tendency towards introversion, in addition to these methods make adolescents live in a world of their own which leads them to fall in various mental disorders, which starts in depression, anxiety and isolation, it also causes a lot of behavioral and moral misconduct, such as abnormal sexual practices, espionage, spreading rumors, lies, bitter feelings and jealousy towards their colleagues. (Al majali, 2007).

In the study Sourander et al. (2010) found that $7.4 \%$ of users of social media had many problems such as: emotional problems, problems with collogues, difficulties in sleeping, and low social behavior (isolation), And behavioral problems.

The negative impact of the means of social communication includes many behaviors and qualities issued by these students, the most important of which are:

1:Abuse of alcohol and drugs.

2: know the experience of violence from criminals.

3: Lack of desire to go to school.

4: low degrees in subjects

5: lack of appreciation and self-confidence.

6. Physical illness (Hajirnis, A. 2015).

\section{RESEARCH PROBLEM AND QUESTIONS}

As a result, it is clear that the spread of social media among adolescent students in the secondary stage has led to serious negative effects: psychological, moral and achievement. So it is important to build values in the light of the Holy Qur'an, to construct The right personality of students, protect help them to cope these negative effects. The current search problem is therefore determined by the following questions:

1. What are the values that proposed in the light of the Holy Quran to cope the negative psychological dangers of the means of social media for the high school students?

2. What are the values that proposed in the light of the Holy Quran to cope the negative moral dangers of the means of social media for the high school students?

3. What are the values that proposed in the light of the Holy Quran to cope the negative achievement dangers of the means of social media for the high school students?

\section{THE QUR'AN ENTRANCE AND IT'S BASIS TO CONSTRUCT VALUES}

Values in the Quran perspective can take it's important form $f$ the sanctity of their Rabbinic source It is the method of the Creator God to raise the creature, which makes them a source of confidence and distance from any lacking. As well as the consent of nature which meets all needs. The 
INTERNATIONAL JOURNAL OF ACADEMIC RESEARCH IN BUSINESS AND SOCIAL SCIENCES

Vol. 8, No. 11, Nov, 2018, E-ISSN: 2222-6990 C 2018 HRMARS

importance of Qur'an values comes from the fact that it emanates from the Universal Deity surrounding all aspects of the human personality that it created and knows what works for it in aspects of life through time and space. And satisfy its material and moral components, as well as keen to interact with all elements of material and moral presence to achieve the humanitarian and social aspects.

"The development of moral values in the Qur'an is based on three basic pillars of the human soul:

(1) the interest in its upbringing and soul because it is the basis of linking the soul with its Creator, and the formation of the strong internal psychological reason for the man who guides his behavior in life and makes him an observer.

(2) The interest in social education on the love, affection and the development of social relations, because the moral core in the Qur'an is focus on respect for the individual and confidence in his ability to distinguish between good and evil for the benefit of the group

3) The interest in educating them about the practice of behavior that achieves moral values (Al-Jarhi, 2007).

\section{THE PROPOSED CONCEPT IN THE LIGHT OF THE QUR'AN APPROACH}

\section{First: The Values of coping the negative psychological effects of the means of social media:}

1) the feeling of good values and believe in fate.

Qur'an is focuses on what is happening for the human in this life is from God's destiny, and some of the difficulties of the world are the test and test of God. Satisfaction with them is a duty, and despair and despair are not permitted God says: "fighting is obligatory for you, though it is hateful to you. But you may hate a thing although it is good for you, and may love a thing although it is evil for you. Allah knows, and you do not. "(AlBaqarah: 261).

2) - The value of trust in God and be optimism:

The expectation of good after hardship is a value that the Quran calls for, and confirms it to the Prophet and to the believers. God says "So, verily, with every difficulty, there is relief, Verily, with every difficulty there is relief." (AshSharh: 5:6).

3) the value of penalty of life

The life is minimum, and the most complete punishment is in the Hereafter. There is no need to worry, depression and sadness over something that is missing from the contents of this world. God says: "Know that the life of this world is but amusement and diversion and adornment and boasting to one another and competition in increase of wealth and children - like the example of a rain whose [resulting] plant growth pleases the tillers; then it dries and you see it turned yellow; then it becomes [scattered] debris. And in the Hereafter is severe punishment and forgiveness from Allah and approval. And what is the worldly life except the enjoyment of delusion." (AlHadid: 20).

4) The value of saving life:

Life in the Qur'an is a great gift from God, and it is given to man, and he must preserve it and do good work, thank God for this blessing. And (remember) when your Lord said to the angels: 
INTERNATIONAL JOURNAL OF ACADEMIC RESEARCH IN BUSINESS AND SOCIAL SCIENCES

Vol. 8, No. 11, Nov, 2018, E-ISSN: 2222-6990 C 2018 HRMARS

"Verily, I am going to place (mankind) generations after generations on earth." They said: "Will You place therein those who will make mischief therein and shed blood, - while we glorify You with praises and thanks (Exalted be You above all that they associate with You as partners) and sanctify You." He (Allah) said: "I know that which you do not know." (AlBaqarah: 30).

Second: The values of Coping the congenital negative effects of social media:

1) The value of levirate of adultery and getting away from it.

The practice of adultery without legal marriage is forbidden, and it is obligatory to limit it. God says: "Do not even go near fornication for it is a very indecent flung and a very evil way" (Allsra: 32).

2) The value of the sanctity of spyware others. God says: "And do not spy or backbite each other " (AlHujurat: 12).

3)the Value of honesty and not lying. God says: The believer is truthful, and he never lies, and lying is one of the characteristics of the double-tongued

"O you who believe! Be afraid of Allah, and be with those who are true" .

4)The value of verifying news, and distance from rumors:

The believer does not follow behind the rumors of ratification or disclosure. Rather, he must confirm and be careful about spreading sedition and exposing people's wrath without knowledge and truth. Otherwise, he will receive punishment in this world, and punishment in the Hereafter. God says "O you who believe! If a wicked person comes to you with any news, ascertain the truth, lest ye harm people unwittingly, and afterwards become full of repentance for what ye have done." (AlHujurat: 6).

5) The value of believers Brothers

The believers are brothers such as the solid which is coherent or so if one member of the body feels pain, their fellow members should come to their aid. God says" Verily, Allah loves those who fight in His cause arrayed in solid ranks, as though they were a strong structure cemented with molten lead" (AsSaff: 4).

6) The value of distance from envy and indignity

Envy is forbidden and always seek refuge in the behavior of a good believer, and the believer must forgive his brother, the believer, for his closeness and obedience to God

God says: "'I seek refuge in the Lord of daybreak " to "And from the evil of an envier when he envies."( AlFalaq: 1:5).

7) The Value of prohibition of gossip and absenteeism:

The idolatry and the absence is a great crime, and the behavior is shameful; it is not appropriate for the believer towards his brother, the believer, and the unjust like someone who eats the flesh of his dead brother. 
INTERNATIONAL JOURNAL OF ACADEMIC RESEARCH IN BUSINESS AND SOCIAL SCIENCES Vol. 8, No. 11, Nov, 2018, E-ISSN: 2222-6990 C 2018 HRMARS

God says :" O you who have believed, avoid much [negative] assumption. Indeed, some assumption is sin. And do not spy or backbite each other. Would one of you like to eat the flesh of his brother when dead? You would detest it. And fear Allah; indeed, Allah is Accepting of repentance and Merciful." ( AlHujurat: 12).

8) The value of forbidden irony from others, and the use of nicknames

It is not allowed to iron from others . God says:" O ye who believe! Let not some men among you laugh at others: It may be that the (latter) are better than the (former): Nor let some women laugh at others: It may be that the (latter are better than the (former): Nor defame nor be sarcastic to each other, nor call each other by (offensive) nicknames: III-seeming is a name connoting wickedness, (to be used of one) after he has believed: And those who do not desist are (indeed) doing wrong. "( AlHujurat: 11).

9) The value of the prohibition of treason, and the need to adhere to honesty and performance:

And the believer leads the secretariats to the people, and never betrays his brother in the promise and the covenant.

God says: "O ye that believe! betray not the trust of Allah and the Messenger, nor misappropriate knowingly things entrusted to you. "(AlAnfal: 29).

10. Value of good work:

True faith is always associated with good work in the Qur'an, and good behavior with God and with people. God says: (through the ages),( Verily Man is in loss), (Except such as have Faith, and do righteous deeds, and (join together) in the mutual teaching of Truth, and of Patience and Constancy.(AIAsr).

Thirdly: The Values of facing the negative effects on achievements for social media:

1) The value of ijtihad, and the rush to seek knowledge:

The diligence in the work is a religious duty, and God and the Prophet witness the work of the Muslim; and therefore must diligence in the work because God sees him and because God rewards him. God says: "so Allah will see your work and (so will) His Apostle and the believers; and you shall be brought back to the Knower of the unseen and the seen, then He will inform you of what you did." (AtTaubah: 105).

2) The value of good works.

The believer is quick to do righteous deeds, and to be saved and mastered in order to seek the face of God, and a desire to win his reward and his paradise. God says : "It is these who hasten in the good deeds." (AlMu'minun: 61).

3) The value of appreciate the life and age.

The life of the world is short, and it is a test from God, and its purpose is to win the paradise. This divine gift must be preserved, utilized and arranged in a way that satisfies God. 
INTERNATIONAL JOURNAL OF ACADEMIC RESEARCH IN BUSINESS AND SOCIAL SCIENCES

Vol. 8, No. 11, Nov, 2018, E-ISSN: 2222-6990 C 2018 HRMARS

God says: "Until, when death comes to one of them, he says: "My Lord! Send me back,(99) "So that I may do good in that which I have left behind!" No! (Kalla) It is but a word that he speaks; and in front of them is Barzakh until the Day. (AIMu'minun: 99:100).

4) The Value of dedication, sincerity to God:

Sincerity in work is a condition for acceptance, hypocrisy corrupts the work, and returns to the owner, does not accept from God Almighty. God says : ' My prayer and sacrifice, my life and death, are all for Allah, Lord of all the Worlds; He has no partner. This is what I am commanded, and I am the first The first 'of you' (AIAn'am: 162: 163).

5) The Value of belonging to one nation:

A Muslim belongs to one nation, great in its goals, and strong in its structure. And belonging to this nation is a great motivation for the believer towards good behavior, towards good work, diligence, excellence and success. God says "This is your nation, one nation, and I am your Lord" (AlAnbiya: 92).

\section{RECOMMENDATIONS}

1 - Conduct researches to identify the psychological, moral and social dangers caused by the means of social communication among young people and adolescents in schools and universities in the Arab and Islamic countries.

2 - Construct values curricula in the light of the Holy Quran, and the Sunnah to address the negative dangers of social networking sites to students of schools and universities in Arab and Islamic countries.

3 - Construct training and awareness programs for teachers, families and students to warn of the dangers of social media, and ways to address them in the light of the Holy Quran and Sunnah.

\section{ACKNOWLEDGEMENT}

Special thanks to Research Management, Innovation \& Commercialization Centre (RMIC) and University Sultan Zainal Abidin (UniSZA) for funding this research

\section{REFERENCES}

The Holy Qur'an.

Al-Jarhi, M. (2007). Development of some educational values for students of the first cycle of basic education in Egypt, in the light of Japan's experience, unpublished doctoral thesis, Zagazig University, Faculty of Education.

Al-Majali, F. (2007). The effect of using Internet upon social relationships among university youth : a field study. AL- Manara, 13 (7), 160-197.

Jalal, A. (2012). The role of social networks in shaping public opinion in Arab society towards Arab revolutions. "A Study Presented at the Sixth Forum of the Saudi Society for Media and Communication": New Media, Theoretical Challenges and applied. King Saud University, Riyadh, 15-16 April 2012.

Quda, M. (2018). Means of communication and its impact on youth. Accessed $13^{\text {th }}$ May, 2018, through website: www.khaberni.com/news/234435 
INTERNATIONAL JOURNAL OF ACADEMIC RESEARCH IN BUSINESS AND SOCIAL SCIENCES

Vol. 8, No. 11, Nov, 2018, E-ISSN: 2222-6990 @ 2018 HRMARS

Sourander, A., Brunstein K., A., Ikonen, M., Lindroos, T., Koskelainen, M., Ristkari, T. \& Helenius, H. (2010). Psychosocial risk factors associated with cyberbullying among adolescents: a population-based study. Arch Gen Psychiatry, 67 (7), 720-728. 